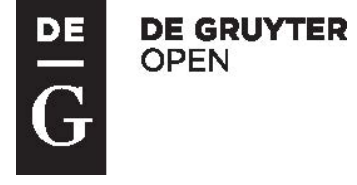

LINGUACULTURE, 1, 2017

\title{
RE-READING SHAKESPEARE'S RICHARD III: TRAGIC HERO AND VILLAIN?
}

\author{
SIOBHAN KEENAN ${ }^{*}$ \\ De Montfort University, Leicester, UK
}

\begin{abstract}
The discovery of the body of the historical Richard III under a Leicester car park in 2012 sparked fresh interest in one of England's most controversial kings. Accused of murdering his nephews - the Princes in the Tower-Richard's reign was cut short when he was defeated by Henry Tudor, Earl of Richmond (later Henry VII), at the Battle of Bosworth (1485). Richard was subsequently demonised in Tudor historiography, perhaps most famously by Sir Thomas More in his "History of King Richard the thirde" (printed 1557). It is to More that we owe the popular image of Richard III as a "croke backed" and "malicious" villain (More 37), an image which Shakespeare has been accused of further codifying and popularising in his Richard III. Today, the historical Richard III's defenders argue for the king's good qualities and achievements and blame early writers such as More and Shakespeare for demonising Richard; but, in Shakespeare's case at least, this essay argues that the possibility of a sympathetic-and even a heroic - reading of the king is built in to his characterisation of Richard III.
\end{abstract}

Keywords: Shakespeare; Richard III; Richard III; tragedy; villainy.

\section{INTRODUCTION}

The discovery of the body of the historical Richard III under a Leicester car park in 2012 sparked fresh interest in one of England's most controversial kings. Accused of murdering his nephews - the Princes in the Tower-Richard's reign (1483-5) was cut short when he was defeated by Henry Tudor, Earl of Richmond (later Henry VII), at the Battle of Bosworth on 22 August 1485 (Horrox). Richard was subsequently demonised in Tudor historiography, perhaps most famously by Sir Thomas More in his "History of King Richard the thirde" (printed 1557). It is to More, for instance, that we owe the popular image of

\footnotetext{
*skeenan@dmu.ac.uk
} 
Richard III as a "croke backed" and "malicious" villain (More 37), an image which Shakespeare has been accused of further codifying and popularising in his play, Richard III. While there is no disputing the fact that Shakespeare's Richard is (like More's), in various respects, a villain and perpetrates a number of terrible deeds, I was struck when re-reading the play recently by the complexity of his portrayal: Richard is not a melodramatic "plain-dealing" villain of the Don John variety (Much Ado About Nothing, 1.3.25) nor an example of the "motiveless Malignity" associated with Shakespeare's Iago (Coleridge 315). ${ }^{1}$ There are reasons for Richard's villainy and he is not without redeeming qualities or a moral compass. Indeed, deeply divided as he is, Richard is a figure for whom audiences are invited to feel some sympathy, and who has more in common with Shakespeare's later tragic heroes such as King Lear and Macbeth than with other famous Shakespearean villains such as Iago. In this regard, I will be arguing that the play is not the straight-forward anti-Ricardian Tudor propaganda it has sometimes been judged to be by later readers and audiences or by some modern historians and defenders of the historical king.

\section{RICHARD III AND TUDOR MYTHOLOGY}

Richard III was the youngest surviving son of Richard Duke of York and younger brother of King Edward IV and George, Duke of Clarence. Having played an important role in his father's war against Henry VI and his brother's eventual accession to the English crown, Richard was - as Duke of Gloucestera powerful and well-respected figure at the Yorkist court, until he effectively deposed his nephew Edward V (after challenging the legitimacy of his birth) and allegedly had Edward and his other nephew (Richard) murdered in the Tower of London (Horrox). However, soon after claiming the English crown, Richard faced a challenge to his rule from the senior Lancastrian claimant to the throne: Henry Tudor, Earl of Richmond (1457-1509), whose mother was the great grand-daughter of John of Gaunt, Duke of Lancaster and $4^{\text {th }}$ son of Edward III. Henry led a successful uprising which culminated in the overthrow and death of Richard at the Battle of Bosworth (1485) and Henry's coronation as Henry VII of England on 30 October 1485. Henry strengthened his claim to the English throne by marrying Edward IV's surviving daughter, and prominent Yorkist, Princess Elizabeth. By uniting the Lancastrian and Yorkist families, Henry brought an end to the so-called Wars of the Roses and founded the Tudor dynasty (Gunn).

\footnotetext{
${ }^{1}$ All quotations from Shakespeare's plays are taken from The Norton Anthology of Shakespeare, edited by Stephen Greenblatt, Walter Cohen, Jean E. Howard and Katharine Eisaman Maus, 1997.
} 
As Stephen Greenblatt notes, the "legend of Richard III's wickedness" had already begun during his lifetime, thanks to his alleged role in the death of his nephews, but it was to grow and become firmly established over the next two centuries, as Tudor historians cultivated his image as a "pitiless, treacherous villain" and thereby justified and legitimated his overthrow by Henry VII (Greenblatt 507). One of the key figures in establishing this negative image of the defeated king was Tudor scholar and humanist, Sir Thomas More. His "History of King Richard the thirde" survives in two versions, an English version, published as part of his Workes in 1557 and a Latin version printed in 1566.

It was More who first emphasised Richard's deformity, positing a link between his allegedly twisted body and his unnatural wickedness and corruption. More's classic indictment of Richard's physique and character is well-known but worth quoting in detail so that we can understand why it proved so influential. According to More, Richard was

little of stature, ill fetured of limmes, croke backed, his left shoulder much higher then his right, hard fauoured of visage, and suche as in states is called warlye, in other menne otherwise, he was malicious, wrathfull, enuious, and from afore his birth, euer frowarde. It is for trouth reported, that the Duches his mother had so muche a doe in her trauaile, that she coulde not bee deliuered of hym vncutte: and that hee came into the worlde with the feete forwarde, as menne bee borne outwarde, and (as the fame runneth) also not vntothed. (More 37)

Elsewhere in his account More offers a similarly memorable description of Richard's propensity for dissimulation which one can see as laying the groundwork for his later presentation as a "consummate role-player" by authors such as Shakespeare (Greenblatt 508). He describes Richard as "close and secrete, a deepe dissimuler, lowlye of counteynaunce, arrogant of heart, outwardly compinable where he inwardely hated" (More 37).

The vividness of More's portrait of Richard (as well as its political convenience) helps to explain its influence, both on the popular reputation and image of the king and subsequent histories and accounts of his reign, including those offered in Polydore Vergil's Historia Angliae (commissioned by Henry VII) and first published in Basle in 1534; Edward Hall's Vnion of the Noble and Illustre Famelies of Lancastre \& York (1548) and Raphael Holinshed's Elizabethan work, The Chronicles of England, Scotland and Ireland, 2 vols (1578), published in a second enlarged edition in 1587.

Most of these histories follow More in presenting Richard as a crookbacked villain, although they vary in some of the details of his story and are sometimes more sympathetic in their portrayal of his younger years. Polydore Vergil, for example, has Henry VI's son (Prince Edward) killed by Clarence, 
Richard and Hastings but also makes "Richard the devoted supporter of his brother Edward, killing Henry VI in order to clear Edward's way to the throne, and having no designs on the throne himself until after Edward's death" (Bullough 224). Similarly, "Hall's account of Richard's youth emphasizes his courage, warlike skill and notable services to Edward at Barnet and Tewkesbury" (Bullough 226) and ends with the acknowledgement that, but for his overthrow and murder of his nephews, Richard might have been admired by history: "Thus ended this prynce his mortall life with infamie and dishonor... And yf he had continued still Protectoure and suffered his nephewes to haue lyued and reigned, no doubt but the realme had prospered and he muche praysed and beloued as he is nowe abhorred and vilipended" (Hall fo. lix).

\section{RICHARD III AND SHAKESPEARE'S RICHARD III}

A century later when Henry VII's grand-daughter, Elizabeth I was on the throne, and Shakespeare came to the story of Richard, the myth of the king as villain was firmly entrenched in the popular and the historical imagination and was consolidated visually in paintings which showed Richard as cruel and humpbacked. Indeed, it is even believed that some portraits of the king were altered in the Tudor era to reinforce negative impressions of Richard (Weir 32). At the same time, Richard's tale remained one which intrigued and fascinated contemporary English men and women. This is presumably why we find several Elizabethan authors engaging with, or adapting, Richard's story. Shakespeare's play of Richard III is now the most famous example of this literary interest in the last Plantagenet king but it is not the only, or the first, Elizabethan work to explore Richard and his reign.

The 1563 edition of A Myrrour for Magistrates (a compendium of moralised tragic tales) features several stories from the period of Richard III, including the complaint of Richard himself, as Duke of Gloucester and the last Plantagenet king (fos cxlvii-cliiii). There were also at least two plays written about Richard's reign before Shakespeare composed his Richard III: the Latin tragedy Richardus Tertius by Thomas Legge, a Professor of Caius College, Cambridge and probably written for performance by university students around 1579 (Bullough 233-4) and the anonymous True Tragedie of Richard the third performed by a rival acting company to Shakespeare's, the Queen's Men (c.1590-2; printed 1594).

Like the historical accounts on which they were based these different fictionalised accounts of Richard generally present the king as an unequivocal villain; and most commentary on Shakespeare's play, which is thought to have been written shortly after the Queen's Men's Richard the thirde, suggests that it does the same. It is certainly true that Shakespeare largely relies on the same 
sources for the play's plot and incidents, his main sources being the histories by Edward Hall and Raphael Holinshed. More controversially, some modern commentators have argued that the lasting fame enjoyed by Shakespeare's Richard III has resulted in the play overshadowing and colouring views of the historical king. Indeed, it has been claimed that "Shakespeare, more than any other, has shaped our reaction to this deeply controversial monarch" (Langley and Jones 34).

Given the popular fame of Shakespeare's Richard III and the relative obscurity of the histories on which he based his play, this is perhaps a fair point, and it is arguably true that Shakespeare's "remains the portrait" of Richard III that "most are drawn to" today (Langley and Jones xi). Likewise, it is true that the fame of Shakespeare's play has proved something of a problem for modern defenders of the king, as Dominic Shellard has recently pointed out: "For those seeking to rehabilitate the reputation of Richard III from centuries of opprobrium (...), Shakespeare's play offers a significant and, at times, irritating challenge" (Shellard 126). However, as I have already indicated, I am not convinced that Shakespeare's Richard is the relatively uncomplicated, straight-forward villain found in most of the Tudor-inspired histories or in the literature of his contemporaries.

Shakespeare's Richard clearly commits villainous deeds, as in the histories that Shakespeare consulted. These include contriving the death of his brother, George, Duke of Clarence, slandering Queen Elizabeth and his nephews, deposing Edward $\mathrm{V}$ and, most controversially of all, ordering the murder of the Princes. But Shakespeare's Richard is nonetheless unusual as a villain and atypical of the preceding histories, not least in the fact that he has proved attractive to audiences and readers, something for which there appears to be no precedent in Shakespeare's sources or the other Richard plays of the period.

Richard's power to captivate audiences helps to explain why so many leading actors have been drawn to the role, including, in modern times, Laurence Olivier, Al Pacino and, most recently, Benedict Cumberbatch. The appeal of Richard's character is not confined to modern times either. An anecdote preserved by lawyer John Manningham in his 1602 diary points to Richard's powerful audience appeal even in Shakespeare's own day.

Upon a time when Burbage played Richard III there was a citizen grew so far in liking with him, that before she went from the play she appointed him to come that night unto her by the name of Richard III. Shakespeare, overhearing their conclusion, went before, and was entertained and at his game ere Burbage came. The message being brought that Richard III was at the door, Shakespeare caused return to be made that William the Conqueror was before Richard III. (qtd. in Greenblatt 507) 
The story is probably untrue but it is implicit testimony to the charisma and attractiveness of Richard's character as played by Shakespeare's leading actor, Richard Burbage. The play's protagonist also appears to have appealed to Shakespearean readers with Richard III proving one of Shakespeare's most popular plays in print, going through six editions before the publication of the First Folio of Shakespeare's plays in 1623, with the first edition of the play appearing in 1597 (Blayney 388).

Scholars have often reflected on why audiences and readers like, and even love, Richard, despite his cruelty and wickedness and have come up with a variety of explanations, including the appeal of his frankness, his wit and his daring, and the fact that he, like the Vice of the old morality plays, invites the audience to be complicit in his plans, sharing with us his schemes in asides and soliloquies, thus putting us in a privileged position compared with most of the characters on stage. We are also invited to admire Richard's skill as an actor, as he variously plays the role of loving brother, kind uncle, ardent lover and pious prince.

But Richard's wit, theatrical talent and seductive appeal are not the only things that mark him out as an atypical villain or a more complex figure than that found in most of the Tudor histories of the last Plantagenet king. Shakespeare's Richard is also an unusual villain in that he is not straight-forwardly amoral as is typical of Machiavellian villains on the Renaissance stage. Perhaps most strikingly, he does not deny the existence of goodness or virtue or their superiority to evil, even though he eschews them in his own life.

\section{RE-READING SHAKESPEARE'S RICHARD AS TRAGIC HERO AND VILLAIN?}

One of the first signs that Richard is not going to be your typical Machiavellian villain is found in his famous opening soliloquy (1.1.1-40). Taken at face value the speech is an overt declaration of villainy; but if we look more closely at what Shakespeare has Richard say the case becomes more complex. Arguably, the key line is the one in which Richard says that he is "determined to prove a villain" (1.1.30). Although this statement could be read as Richard saying that he will provide "proof" of his native villainy, it could also be read as wilful, indicating his wish to become or make himself a villain, suggesting that his villainy is not inherent. At the same time, as many have observed, Richard's preceding account of himself suggests a motive for his villainy, implying that it is partly a response to his society's negative expectations and marginalisation of him because of his deformity. This might be a convenient excuse, but it could also be a way of Shakespeare suggesting that evil is made as well as born. 
The same soliloquy also exemplifies a trait that Richard displays throughout the play which is his capacity for self-critique. Indeed, he is arguably his own harshest critic in the world of the play. He poignantly describes himself as "Deformed, unfinished" (1.1.20) and implicitly mocks himself, noting that he is so unsightly that dogs bark at him. He speaks in similar terms about his ugly and "misshapen" body (1.2.237) several times in the play and is quick to mock himself elsewhere, too, as when he starts imaginatively racing ahead with his plans at the end of the first scene, after receiving news of the king's illness: "But yet I run before my horse to market,/Clarence still breathes, Edward still lives and reigns,/When they are gone, then must I count my gains" (1.1.160-2). Richard is similarly candid about his corrupted character, as when he first reveals his plot against Clarence, contrasting his own "subtle false and treacherous" character (1.1.37) with the "true and just" character of his brother, the king (1.1.36).

Stephen Greenblatt suggests that Richard's willingness to self-identify himself as ugly and wicked is evidence that he "has internalised the loathing that he inspires in virtually everyone around him" (Greenblatt 509), but, as his description of Edward IV suggests, Richard also recognises and, at points, admires virtue, despite the fact that he identifies himself with the devil and the amoral philosophy of Machiavelli, talking of how he plays "the devil" (1.3.336) and in the preceding history play, Henry VI, Part III, declaring: "I can add colours to the chameleon, / Change shapes with Proteus for advantages, / And set the murderous Machiavel to school" (3.2.191-3).

Richard knowingly (and sometimes gleefully) acts immorally but he does not appear to reject the existence of "a divinely sanctioned, objective moral order" (Bullough 509). On the contrary, he sometimes expresses something close to longing for an idealised virtue and goodness in a world that is, in his eyes, as corrupt as himself for the main part. We see this most vividly in the soliloquy in which he praises Prince Edward, son of King Henry VI and the betrothed of Lady Anne, after his wooing of Anne.

Richard's seduction of Lady Anne is one of the play's most memorable scenes and one of Richard's most impressive persuasive feats, as he succeeds in winning over the widow of the Prince he has slain while she mourns over the dead body of the father-in-law he has also murdered, wooing her in her "heart's extremest hate", as he puts it (1.2.219). When Lady Anne leaves the stage, Richard's soliloquy reveals that he is impressed and amused by his success as a wooer but he is also implicitly disappointed with the Lancastrian widow, believing that she should not have been wooed by him (1.2.215-25). Even more striking, however, is what he goes on to say about her dead husband, Edward, the Prince he has slain (in Shakespeare's version of events):

Hath she forgot already that brave prince,

Edward her lord, whom I some three months since 
Stabbed in my angry mood at Tewkesbury?

A sweeter and a lovelier gentleman,

Framed in the prodigality of nature

Young, valiant, wide, and no doubt right royal,

The spacious world cannot again afford-

And will she yet abase her eyes on me,

That cropped the golden prime of this sweet prince

And made her widow to a woeful bed?

On me, whose all not equals Edward's moiety?

On me, that halts and am misshapen thus? (1.2.226-37)

Here we find Richard holding up Edward as a paragon of princely and manly virtue and a figure deserving of love and admiration. This is completely at odds with his own self-description. At such a moment, Shakespeare's Richard appears to be a frustrated idealist - a man who chooses evil because he is not allowed to be virtuous and because the world is not virtuous.

Fresh proof that Richard feels an element of distaste for his own actions and their success is afforded by his response on other similar occasions, where he persuades people to believe his lies. Repeatedly, Richard mocks and critiques those who allow themselves to be falsely persuaded by him. This is partly arrogance and borne out of contempt for their weakness, but it also seems to be about disappointment with people and a world in which his deceptions succeed. Thus, he mocks "simple plain Clarence" (1.1.119) for being taken in by his pretence of love and loyalty. Likewise, he mocks the courtiers who believe him when he claims that Queen Elizabeth is responsible for Clarence's plight (1.3.325-36), revealing at the same time how he clothes his "naked villainy" (1.3.334) with "odd old ends, stol'n forth of Holy Writ" (1.3.335). Similarly, just as he criticises Lady Anne for being wooed by him so later in the play's second "wooing" scene with Queen Elizabeth, he is excoriating when he thinks his persuasive rhetoric has won her over to support his plan to marry her daughter, Princess Elizabeth, condemning the queen as a "relenting fool, and shallow, changing woman" (4.4.362). As in the scene with Lady Anne, Richard seems morally disappointed by his success and disapproving of the woman who could be seduced by him, criticising her for being fickle (even though this is what he has been persuading her to be).

That Shakespeare's Richard is not the wholly ruthless and hard-hearted Machiavel he is sometimes painted as would, likewise, seem to be suggested by his attitude to his critics. Although Richard is frequently dismissive of his opponents and their condemnations of his actions, he is not entirely immune to their criticism; it does appear to touch him at points, in a way that one would not expect of an entirely wicked character. We see this most strikingly in Act 4 scene 4. This is the scene in which Richard is confronted by his mother, the Duchess of York, Queen Elizabeth and Queen Margaret on his way to prepare 
for battle with Richmond. The women are keen to speak to him and (as the audience knows) to curse him for his crimes against them and their loved ones. Richard's first response is to say that he will not listen to the women and he moves to silence them symbolically, calling for a "flourish" of trumpets to drown out the "tell-tale women" $(4.4 .149,150)$. But Richard goes on to suggest that he will listen if they are "patient" and will "entreat" him "fair" (4.4.152).

When his mother starts to talk he initially interrupts her, quipping about his need for haste, but, eventually, Shakespeare has him choose to stop and listen to her, even though he does not need to do so and must know that criticism is to follow. He also shows a painful awareness that he is "disgracious" (4.4.178) in his mother's eyes. The Duchess of York proceeds to curse him (4.4.184-96), prophesying that "Bloody thou art, bloody will be thy end; / Shame serves thy life, and doth thy death attend" (4.4.195-6). That Richard's mother should curse him in this way is especially shocking. For once he does not respond; there is no witty quip. Temporarily, he appears to have been silenced. Even more surprisingly, Richard has chosen to expose himself to this cursing, almost as if he does not wish to avoid criticism and believes he deserves such condemnation and the bloody end which the Duchess predicts for him.

That the Duchess' words (and the words of his other critics) have touched him appears to be confirmed when Richard finds himself haunted by his victims and experiences his first serious pangs of conscience on the eve of the Battle of Bosworth (5.5). The dream scene vividly enacts the return of Richard's sins to haunt him - as embodied by the ghosts of those he has killed - but it is his reaction to their reminder of what he has done that is most striking. Richard may have started the play determined to "prove a villain" (1.1.30) and ready to praise those who claim to be able to set aside pity and conscience, like the murderers he hires to kill Clarence (1.3.351-2), but he discovers too late that he cannot eschew his own conscience or morality so readily or wilfully. Here, Shakespeare may be making a point about the difficulty of trying to sustain a Machiavellian amoral approach to power and pointing to the existence of a divinely sanctioned morality.

Richard may condemn "coward conscience" but there is no escaping the fact that in this scene he has, and is haunted by, a conscience (5.5.133); and it is here that we see Richard at his most deeply divided as he disputes with himself about the morality of his life and his deeds. Again, this includes being his most open and honest critic, baldly describing himself as a "villain" (5.5.145) and a "murderer" (5.5.138), guilty of "hateful deeds" (5.5.144). Richard contemplates self-punishment both for what he has done to others and (implicitly) for what he has done to himself:

Then fly! What, from myself? Great reason. Why?

Lest I revenge. Myself upon myself? 
Alack, I love myself. Wherefore? For any good

That I myself have done unto myself?

O no, alas, I rather hate myself

For hateful deeds committed by myself. (5.5.139-44)

Richard may suggest that he deserves no pity and does not feel it for himself (5.5.155-7), but it is hard for an audience not to feel some sympathy for him at this moment, even though (and perhaps because) he has brought this anguish on himself, not realising the true cost of his evil actions.

The visitation of the ghosts and his conscience-stricken debate with himself leave Richard knowing that his end, and the fulfilment of his mother's and the ghosts' prophecies, is probably near at hand but the way that he faces this imminent end is again, interesting. He does not panic or become filled with self-pity. On the contrary, Richard goes on to face his death bravely, rather like Macbeth. Indeed, although Richard may end up dismissed and degraded by Richmond as a "bloody dog" (5.8.2) following his defeat, Shakespeare's handling of Richard's final moments on stage is more surprising and poignant. As well as making a powerful leader's speech to his men, Richard goes on to lead by example, Catesby reporting on his personal bravery and physical courage during the battle: "The King enacts more wonders than a man, / Daring an opposite to every danger" (5.7.2-3). When we eventually see Richard he is in a more desperate plight, unhorsed but keen to find and fight Richmond (5.7.7$13)$.

Like Shakespeare's Macbeth after him, Richard eventually falls and his sinful pursuit of power and ambition is punished with an inglorious death, as prophesied by his fellow characters and in keeping with the fate met by the historical Richard; but, in his final moments Shakespeare presents Richard as brave and, in his own, way, heroic. In allowing Richard the redeeming quality of courage, Shakespeare also further complicates his portrayal of the Yorkist as a villain. This final emphasis on his martial bravery was perhaps suggested to Shakespeare by the more positive handling of Richard's early career as a fighter in the histories of Edward Hall and Polydore Vergil, but it also serves to confirm Richard's status as tragic hero as well as historic king.

\section{CONCLUSIONS}

Richard III and his Shakespearean namesake continue to be the subject of considerable popular interest today, as demonstrated by the excitement generated by the discovery of Richard III's body in Leicester (2012) and by the BBC's recent Hollow Crown adaptation of Richard III, directed by Dominic Cooke and starring Benedict Cumberbatch (2016). The rediscovery of Richard III's body has encouraged us to re-appraise our knowledge of the king and to re- 
interrogate the negative mythology his career generated in and after the Tudor era. In the same way, I would argue that it is time to revisit readings of Shakespeare's Richard III which dismiss Richard as a stereotypical Machiavellian villain and the play as no more than belated Tudor propaganda.

Shakespeare's Richard is a self-confessed villain, but he is far from a typical stage Machiavel and a more complex character than is often acknowledged, especially ethically. Shakespeare's Richard does not deny the existence or superiority of virtue. On the contrary, even though he chooses its opposite, he, at times, expresses admiration for goodness and the ideal it represents in a fallen world. Like Shakespeare's later tragic heroes, Richard is flawed but he also possesses tragic stature in the face of his fall which is presumably why the play, when first published was entitled, The Tragedy of King Richard the third (1597), rather than simply a history of the king.

Today, the historic king's champions and defenders argue for recognition of King Richard's talents and achievements in power and criticise early writers such as Sir Thomas More and Shakespeare for demonising and caricaturing Richard unfairly; but, in Shakespeare's case at least, I hope that I have shown that the possibility of a more sympathetic - and even a heroicreading of the king is actually built in to the characterisation of Richard III as a flawed, divided and charismatic tragic hero. Indeed, it may be the life-like complexity and contradictions of Shakespeare's Richard, as much as his verbal wit and theatrical dexterity, that explain the long-life of the play and the continuing power of its leading character to fascinate and enthral audiences on and off the stage and the page.

\section{Works Cited}

Blayney, Peter W. M. "The Publication of Playbooks". A New History of Early English Drama. Ed. John D. Cox and David Scott Kastan. New York, Columbia University Press, 1997. 383-422. Print.

Bullough, Geoffrey, ed. Narrative and Dramatic Sources of Shakespeare, Volume 3 Earlier English History Plays: "Henry VI", "Richard III", "Richard II". London: Routledge and Kegan Paul, 1960. Print.

Coleridge, Samuel Taylor. Lectures 1808-1819 On Literature 2. Ed. R. A. Foakes. Princeton, New Jersey: Princeton University Press, 1987. Print.

Greenblatt, Stephen. "Introduction". William Shakespeare, Richard III. The Norton Shakespeare. Ed. Stephen Greenblatt, Walter Cohen, Jean E. Howard and Katharine Eisaman Maus. New York: Norton, 1997. 507-14. Print.

Gunn, S. J. "Henry VII (1457-1509)". Oxford Dictionary of National Biography. Oxford University Press, 2004; online edn, Jan 2008. Web. 10 Jan 2017.

Hall, Edward. The Vnion of the Two Noble and Illustre Famelies of Lancastre \& Yorke. London: Richard Grafton, 1548. Print. 
Horrox, Rosemary. "Richard III (1452-1485)". Oxford Dictionary of National Biography. Oxford University Press, 2004; online edn, May 2013. Web. 10 Jan 2017.

Langley, Philippa and Michael Jones. The Search for Richard III: The King's Grave. London: John Murray, 2013. Print.

More, Thomas. "The History of King Richard the Thirde (vnfinished)". The Workes of Sir Thomas More Knyght. London: Iohn Cawod, Iohn VValy and Richarde Tottell, 1557. 35-71. Print.

Richard III. Dir. Dominic Cook. Perf. Benedict Cumberbatch. 2016. London, 2016. DVD.

Shakespeare, William. The Norton Shakespeare. Ed. Stephen Greenblatt, Walter Cohen, Jean E. Howard and Katharine Eisaman Maus. New York: Norton, 1997. Print.

Shellard, Dominic. "A King Rediscovered: The Economic Impact of Richard III and Richard III on the city of Leicester". Shakespeare's Cultural Capital: His Economic Impact from the Sixteenth to the Twenty-First Century. Ed. Dominic Shellard and Siobhan Keenan. Basingstoke: Palgrave Macmillan, 2016. 126-47. Print.

The Tragedy of King Richard the third. London: Andrew Wise, 1597. Print.

"The tragical doynges of Kynge Richard the thirde". A Myrrour for Magistrates. London: Thomas Marshe, 1563. Fos cxlvii-cliii. Print.

The True Tragedie of Richard the third. London: Thomas Creede, 1594. Print.

Weir, Alison. Richard III and the Princes in the Tower. London: Vintage, 1992; repr. 2008. Print. 